\title{
Development of In House Training Module to Improve Basic Teachers ICT Competency
}

\author{
Dewi Hariany ${ }^{1 *}$, Happy Fitria ${ }^{2}$, Achmad Wahidy ${ }^{2}$ \\ ${ }^{1}$ SDN 12 Rambutan Kabupaten Banyuasin \\ ${ }^{2}$ Universitas PGRI Palembang \\ *Corresponding author. Email: harianydewi@gmail.com
}

\begin{abstract}
This study aims to develop an In House Training module for elementary school teachers to improve ICT competence. Types of this research was $\mathrm{R}$ and $\mathrm{D}$ that go through seven stages, namely: research and information gathering, planning, initial product design, design validation, product revision, limited trial, and product revision. The research subjects were teachers at primary school (SDN) 12 Rambutan, Rambutan District, Banyuasin Regency. Data analysis used the Fish Bone diagram, in descriptive form. The final product of the research is an In House Training module entitled "Knowing PowerPoint 2007". The use of modules as a medium for In House Training is considered to be able to improve teachers' ICT competence. The module is expected to be used as an independent learning medium in the use of the PowerPoint presentation application along with the use of the internet and the operation of the LCD projector.
\end{abstract}

Keywords: Modules, In House Training, ICT.

\section{INTRODUCTION}

In the Education is considered to have transformed into a fundamental need for humans. Given the importance of education, humans are increasingly placing education on the main axis so that it is able to deliver humans to the progress of the times. In essence, education is a process of liberating students from ignorance, incompetence, helplessness, untruth, dishonesty, and from bad hearts, morals and faith [1]. This makes education very important because over time, humans are required to escape from the ignorance inherent in ignorance.

Quality education is expected to be able to create creativity. For this reason, quality education is the main reason someone looks for a school as a place of learning. This is supported by [1] who says that quality education is born from a good planning system, with materials and a good governance system and delivered by good teachers with a quality education component, especially teachers. With a combination of a good planning system, using good systems and governance, and being implemented by good teachers, quality education is ready to keep up with the changing times.

Mulyasa [1] says that quality education is born from quality teachers. Teachers should have academic qualifications and competencies. In addition to the need for qualified and competent teachers, schools must provide appropriate infrastructure to support education in these schools. This is also supported by [2] who says that being a professional teacher means that a teacher's job can only be done by someone who has academic qualifications, competence, and teacher certification. If a person does not have the academic qualifications and competencies in question, then the quality of the resulting education will decline over time. With qualified teachers and adequate educational facilities, education must of course be supported by a curriculum that has been established by the government. Public Elementary School (SDN) 12 Rambutan, Rambutan District, Banyuasin Regency is a school the level of achievement is good, this is evident from the students of SDN 12 Rambutan who won 2nd place in the implementation of the National Student Sports Olympiad (O2SN) at the elementary school level (SD) in the field of Natural Sciences (IPA) in 2018 and in 2019 again 2nd place in O2SN for Elementary School Mathematics in Banyuasin Regency.

In the same year, mid-2019, SDN 12 Rambutan, the school accreditation level, received a very good predicate, namely accredited A. And in early 2020 SDN 12 Rambutan became one of the pilot schools with a total of 17 groups of study groups (groups) consisting of 17 groups. most in Rambutan District, Banyuasin Regency for SD level. Teaching methods that are still conventional are one of the weaknesses in SDN 12 
Rambutan, of the 17 teaching staff who are classroom teachers no more than $25 \%$ are able and can present lessons using computers. Educational facilities in the form of multimedia at SDN 12 Rambutan are classified as adequate, including 2 liquid crystal display (LCD) projectors, 1 computer unit, 7 laptops, and an internet network. With a total of 23 teachers, only 1 or 2 teachers use laptops as learning media, but LCD are not used as learning media.

SDN 12 Rambutan has already implemented a 2013 curriculum trial in 2013, so SDN 12 Rambutan teachers already know a lot about the teaching system. This thematic curriculum 2013 requires material that does not only refer to 1 teaching material such as textbooks distributed by schools, but materials can be obtained from any source such as the internet or other books that can be used as sources. Answers, which differ from each student and come from different sources, require the teacher to summarize and present it to students. To make it more interesting, the summary made by the teacher can be presented using audio-visual or multimedia media.

According to Effendi [3], the application and adaptation of technology in learning spaces is a necessity in facing changes in the era of globalization, the development of information and communication technology has had an impact on the world of education, especially in the learning process. Technological developments have given birth to innovative and creative learning models in the learning process.

Meanwhile, according to Phillip quoted by Reddi [4], multimedia is a presentation tool that has the characteristics of a functional combination of text, images, sound, animation, and video, some or all of which are organized into a coherent program. By using learning media in the form of multimedia, teachers can make appropriate use of existing educational facilities. Supported by learning and educational technology, the teaching and learning process is expected to be more interesting. Contrary to this, the competence of teachers in utilizing multimedia is very limited which in turn causes constraints in the use of multimedia at SDN 12 Rambutan, because according to Musfah [5] the use of multimedia in learning can teach something new to students and schools are able to face change confidently. To get around this, the competence of Information and Communication Technology (ICT) teachers needs to be improved. One strategy to improve teacher ICT competence is through In-House Training (IHT) or home training.

Competence is an action or performance that describes the potential, knowledge, skills, and attitudes associated with a particular profession [6]. This definition shows that competence is a complete unit that describes a person's appearance, abilities and behavior. Teacher competence is related to the concept of the nature and duties of the teacher, namely a set of knowledge, skills, and behaviors that must be possessed, lived, mastered, and actualized by the teacher in carrying out their professional duties. These competencies consist of pedagogical, professional, personal, and social competencies (Law of the Republic of [7].

One of the indicators of teacher competence that concerns the author is the competence of Information and Communication Technology (ICT). Teacher's Information and Communication Technology (ICT) competence is the teacher's ability to develop learning innovations by utilizing ICT both in planning, implementing, and evaluating learning, both in pedagogic, personal, professional, and social competency aspects. According to the Regulation of the Minister of National Education Number 16 of 2007, the competence of Information and Communication Technology (ICT) for teachers has at least two functions, namely Information and Communication Technology (ICT) as self-development and Information and Communication Technology (ICT) as a support for the learning process [8].

Determination of Information and Communication Technology (ICT) competencies as one of teacher competencies is a logical consequence of the large positive influence of Information and Communication Technology (ICT) for educational activities, such as: accelerating teacher access to various learning resources, accelerating teacher administrative work, helping teachers in explaining abstract and complex material, and making it easier for teachers to send their performance reports to government portals [9] and information and communication technology can be used to revitalize the learning process which in turn can adapt students to the environment and the world of work [10]. Therefore, in addition to having the ability to teach in class, teachers must also be able to integrate the use of ICT in learning.

Along with the rapid development of Information and Communication Technology (ICT), there are still several problems related to the competence of Information and Communication Technology (ICT) for elementary teachers, namely: a) Projectors available in classrooms and in teacher offices are rarely used. The teacher's reasons for not using the projector are: hassle, afraid of short circuit, the children make noise when using the projector, do not have digital teaching materials to present, cannot make power point media, and cannot connect the projector to a laptop. b) The use of computer and language laboratories in established primary schools is also less than optimal. The reasons why teachers are reluctant to use laboratories are: teachers are comfortable with learning verbal learning methods and are not comfortable with learning using Information and Communication Technology (ICT) 
devices. Computers that are damaged are not repaired immediately so that the number of computers that can be used is less than the number of students who will use it. The problem of competency in Information and Communication Technology (ICT) for elementary school teachers is a joint responsibility of the government, schools, communities, and teachers themselves.

Apart from the problem of teacher competency in Information and Communication Technology (ICT), we cannot deny that other problems exist in the field, such as in Rambutan District, where there are 16 public elementary schools, some of which are located in areas far enough from the district capital so that there is no access to electricity adequate. Even though access to electricity is very much needed in the use of multimedia education facilities to support Information and Communication Technology (ICT) in schools, of course this hinders the performance of teachers in applying Information and Communication Technology (ICT) in the school environment.

Based on the explanation above, the researcher felt the need to help teachers and school principals prepare a guide and further research on In-House Training Module Development to Improve Information and Communication Technology (ICT) Competence for Primary School Teachers.

\section{METHODS}

\subsection{Types of Research}

This study used Research and Development (R \& D) model. This research is also called development research that is used to produce certain products and test the effectiveness of these products. Mulyatiningsih [12] explains that the purpose of $\mathrm{R} \& \mathrm{D}$ is to produce new products through the development process of integrated research activities during the product development process.

The product developed in this study is the In-House Training (IHT) module which is used to improve the competence of Information and Communication Technology (ICT) among elementary school teachers. This type of research is research and development or $\mathrm{R}$ \& D with a qualitative descriptive approach. In this study, the development model uses a procedural model, where this model is descriptive, to outline the steps taken to produce a product. The Research and Development ( $R$ \& D) design used in this study is a design developed by Borg and Gall [11].

This design has 10 general stages, namely research and information gathering, planning, initial product design, design validation (expert testing), product revision, limited trial, product revision, operational field trial, final product revision, implementing and disseminating the product. Of the ten stages, this development research will only be carried out until the seventh stage, because after a limited trial, the In House Training (IHT) module can be used in schools as IHT media and independent learning media.

\subsection{Research Subjects and Data}

The subjects in this study were class teachers and principals of SDN 12, Rambutan District, Banyuasin Regency. To collect research data, the researcher carried out three activities, namely 1). Literature study for preparation of field data collection was performed; 2). Analyze data from the preliminary study results and describe the field data findings (factual design) and 3 ). Preparation of the initial product or initial draft of the developed module design was also performed.

Collecting data using observation techniques, interviews, questionnaires, study documentation, and reviewing relevant research conducted on 17 classroom teachers and 1 school principal at 12 Rambutan Public Elementary School (SDN), Rambutan District, Banyuasin Regency, but the class teachers who become The core respondents at the In House Training (IHT) trial phase later were 11 class teachers and 1 school principal, so that a total of 12 respondents were obtained. This research was started from October to December 2020

\section{RESULTS AND DISCUSSION}

Based on the research that has been carried out, the module development stage of In House Training (IHT) focuses on three things, namely module material, training material, and information and communication technology (ICT) material. To measure the validity, practicality, and effectiveness of their use, researchers conducted an evaluation and to measure parameters consisting of expert evaluation and limited trial evaluation. The stages are as follows:

\subsection{Research and Information Gathering}

At this stage, researchers are used to analyze needs, study literature, and identify the factors that become problems, so there is a need for product development. Collecting data using observation techniques, interviews, questionnaires, documentation studies, and reviewing relevant research were carried out.

From all available data, the researcher conducted a problem analysis to find out what the SDN 12 Rambutan teachers needed by using a Fish Bone diagram as shown in Figure 1. 


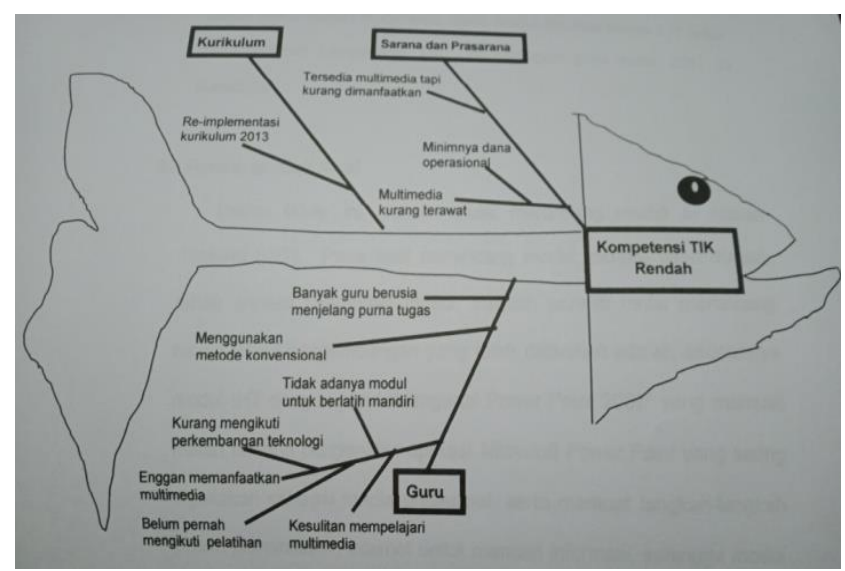

Figure 1. Fish Bone Diagram

Based on the description of the needs analysis, from the Fish Bone diagram above, these problems include: in terms of facilities and infrastructure, multimedia is available in schools and private property but is not optimally utilized, existing multimedia is poorly maintained due to lack of operational funds From the teacher's point of view, many teachers are approaching retirement age so that learning in class is still carried out conventionally, many teachers do not keep up with technological developments, some others, feel reluctant to take advantage of multimedia and have difficulty learning multimedia. Lack of available modules that can be used as a means of independent training for multimedia learning, and there is no special training in schools to improve competency in information and communication technology (ICT).

The findings of the problems in the field indicate that in the 2013/2014 school year SDN 12 Rambutan has started implementing the 2013 curriculum, according to a circular from the Head of the Banyuasin Regency Education and Culture Office. Based on interviews with teachers, it is known that many are still using conventional teaching methods, while a lot of material is not included in teaching materials but must be taught to students. This causes them to miss the material that should be taught, but they choose to teach things that are only in the teaching material because they find it difficult to find sources. Their ignorance of using technology makes them feel they are experiencing setbacks in terms of teaching.

Another thing that causes teachers to be reluctant to use existing multimedia is their inability to operate these tools. This is because many teachers have never received similar training, and there are no modules that can be used for independent learning. Some teachers admitted that they had tried to operate the multimedia, but they had difficulty remembering the steps that had been taught by fellow teachers at SDN 12 Rambutan, because it was done orally and in a limited time. This was done to support the implementation of the 2013 curriculum at SDN 12 Rambutan.

There are several multimedia that can actually be used by teachers in the teaching and learning process, but many of them are reluctant to use it because it takes a lot of time to prepare. Many of them feel that conventional methods are less than optimal in the teaching and learning process. The responses given by students tend to be passive, therefore the teaching and learning process is teacher-centered.

In some teachers who have used multimedia in the teaching and learning process, they observe that students tend to be more active and ask to use multimedia more often in the classroom. However, because of the many obligations that must be done, they only used multimedia as a learning medium several times. Multimedia at SDN 12 Rambutan is more used to do educational administration, which is mostly managed by one administrative staff. The existence of an internet network at SDN 12 Rambutan has also not been used optimally for the benefit of the teaching and learning process.

Some teachers use the internet to open social media using their cell phones, but they do not use it to find supporting materials for the teaching and learning process. The school computer, which only has 1 unit, looks poorly maintained, because it has been damaged for a long time. This is only left unchecked because of the lack of managers who can solve the problem. In addition, the lack of operational funds for multimedia is an excuse for improper maintenance.

From the observations made by the author in the classroom, it can be seen that several learning media are taped to the wall such as: multiplication, division, addition, subtraction, perfect five healthy pictures, alphabet and number models, skeleton models, maps of the State of Indonesia, globe as well as types of regional dances. The teaching and learning process in the classroom also seems monotonous, because some students in grades one and two are seen playing when the teacher teaches in front of the class. In observations in grades three, five, and six, the authors observed that the teachers used more conventional methods. The students who sat in the front row seemed to pay attention, but the students who sat in the back tended to talk to their friends, even some of them were playing. The difference in student responses can be seen in the teaching and learning process in grade four, where the teacher uses instructional videos in the form of short films which are presented using a laptop and LCD projector. Almost all students watched the film with high enthusiasm. 
The facts that occur in the field are in line with those expressed by [13] regarding the reasons for the low utilization of multimedia previously described. With regard to mastery of ICT competencies that fall into the pedagogical realm, meeting training needs is an important issue in problems in the field. As stated by [14], strategies that can be implemented to increase knowledge and skills so as to increase productivity are by conducting training. In this case, In House Training (IHT) is an option as a strategy to improve ICT competence for teachers at SDN 12 Rambutan.

From the problems that have been found above, the implementation of In House Training (IHT) training using special modules to improve the ICT skills of teachers in schools is very important to do, as the researchers conducted at SDN 12 Rambutan.

\section{Planning}

From the results of research that has been carried out through interviews, observation, distributing questionnaires, and documentary studies, it was found that the ICT competence of SDN 12 Rambutan teachers was very low, so it needed In House Training (IHT) in the use of multimedia, as well as modules as IHT media for improve ICT competence among SDN 12 Rambutan teachers.

\section{Initial Product Design}

The preparation of this module begins with the collection of information as a foundation in analyzing needs. Needs analysis is carried out as a guide in module preparation. The preparation of this module is carried out in stages, adjusted to the needs of the teacher. In the first stage of preparation, material about the introduction of the Microsoft Power Point application was compiled, starting from opening the application and introducing the basics of PowerPoint. Once participants are able to start opening the application, they start making presentations, as well as changing and editing text. The next material is how to make the presentation format more attractive. It is intended that the presentation display is able to attract students' attention. That way, learning materials that are considered complicated will be better conveyed.

The module also includes material on how to insert objects and tables in the presentation. This has the aim that the presentation that is presented later can contain the content needed by the teacher, for example in mathematics the teacher can enter data in tabular form in the presentation. Teachers in grade one and grade two can make the teaching and learning process more interesting by inserting animation into the presentation. This module also provides material for running presentations that have been made in the form of a slide show.
The last material that is included is the use of the internet. This material aims to provide other options for teachers in finding teaching materials via the internet. Supported by the availability of an internet network at SDN 12 Rambutan, teachers want to use the internet more optimally.

\section{Design Validation (Expert Test)}

Validity is defined as a measuring tool, but it is not generally accepted for all measurement purposes. A measuring instrument produces a valid measure only for one specific measuring purpose. Not all measuring instruments can produce valid measurements for various measuring purposes. Therefore, a statement such as "this measuring instrument is valid" is not complete if it is not followed by information indicating its purpose, which is valid for what and valid for whom [15]. This development research resulted in the In House Training (IHT) module. The development design of this IHT module is according to Borg and Gall's development procedures.

The initial stage that the researchers took to test the validity was to evaluate the first draft. The process of testing the validity of the IHT module by carrying out expert trials. The expert trials referred to are module experts, training experts, and information and communication technology (ICT) experts.

The training module design validation was carried out by Budi Nopriyadi who is a staff of the training section of the UPTD BLKPPKT Disnakertrans of South Sumatra Province, as a training expert, module expert, and ICT expert. Validation of the module design is carried out to obtain an assessment of the quality of the module, so that it can be used to revise material and improve module quality. The results of the module design validation were obtained through an assessment using a validation sheet. Based on the results of the validity test conducted by expert experts, there are general comments and suggestions about the module, namely:

1. The module entitled Knowing Power Point 2007 is good, but you only need to pay attention to the use of a watermark on the start and end pages to consider replacing a lighter color or simply removing it. It is feared that this will disturb the concentration of participants in studying the module content, because the display of colors that is too bright and bright will disturb the clarity of writing in the module.

2. In the aspect of clarity, examples of presentation images in the module, it is necessary to pay attention to the clarity of the letters in the red box to be enlarged because of the consideration that many 
training participants are followed by teachers who are nearing retirement.

3. The material for the practice assignments in the module is good, but in the training session participants may choose the material to be typed on the presentation slide.

Based on the expert's judgment, it can be concluded that the training module is declared good and feasible to be tested in the field with revisions according to the suggestions. All input from experts will be used to revise the module so that it is worth testing.

\section{Product Revisions}

Based on the results of expert expert judgment, improvements were made according to expert advice. Researchers made improvements to the use of watermarks (watermarks) on the start and end pages by replacing a lighter color or simply removing them. So that with this revision it will not disturb the concentration of the participants in studying the module content, because the color display is not too bright and does not interfere with the clarity of writing in the module.

In the aspect of clarity, examples of presentation images in the module, the researcher made corrections to the letters in the red box to be enlarged because of the consideration that many training participants were followed by teachers who were nearing retirement. So that the teachers are able to read every word in the module clearly. For the training assignment material in the module it is good, but there is still a need for revision in the training session where participants can choose the material to be typed on the presentation slide according to the class that the teachers are effective at or in other words the teachers immediately make slides for the material used as media classroom learning.

\section{Limited Trial}

After the module has been revised by experts and made improvements according to expert advice, the module is ready to be tested in In House Training (IHT) among SDN 12 Rambutan teachers. A limited trial was conducted to test how feasible the module being developed was as a training medium. IHT takes place 10 times, where each meeting discusses one chapter of material. Of the ten meetings, the meeting was attended by all teachers and school principals and not only 12 core respondents because all teachers were very enthusiastic about the implementation of this IHT so all teachers wanted to be involved in this IHT. However, the attendance list was filled only by class teachers and school principals who were the core respondents in this study. Teacher attendance at IHT is recorded in the IHT attendance list.
At the eighth meeting, the writer directed participants to present the results of making a presentation in accordance with the instructions in the practice questions using the LCD projector. Before operating the LCD Projector, the author provides additional information about how to operate the LCD projector verbally. However, the participants suggested that the steps for operating the LCD projector are also included in the module material, so that one day they can operate the LCD projector independently by referring to the material in the module.

At the end of the meeting, the author was assisted by a staff of Administration (TU) with an educational background of D3 Information and Communication Technology to repeat the material from the beginning to the end of the module, with the aim that one day the teachers can practice independently, and if they have difficulty finding information through their counterparts. The input result from the limited trial phase was to add material on the steps to operating the LCD projector into the learning material in the IHT module. This is so that the trainees are able to operate the LCD projector independently by referring to the IHT module.

At the end of the training, the authors conducted interviews with training participants regarding the results of product trials. In the post IHT interview, it was found that the preface in the module explained the module's function. The table of contents in the module already contains an outline and is accompanied by page numbers very clearly. The learning objectives include the achievement of competencies for training participants. Instructions for using the module can be understood by participants. Every material in learning can be understood and implemented easily. The evaluation exercise assignment is easy to understand and undertake by participants and participants may choose other material that they want to type in the presentation slide according to the material guide in the module.

The glossary already contains words that have not been understood, so that participants do not have difficulty understanding words that are considered difficult. From the results of the interviews, the modules that were tested were accepted and used in In House Training (IHT) to improve ICT competence among elementary school teachers. The feasibility of this module is measured from the results of the evaluation exercises contained in the module. The module is declared eligible to be accepted and used as IHT media if the training participants can work on any existing evaluation exercise tasks without seeing the material in the module. And when the training has been completed, 
the teacher can apply the material that has been obtained during IHT into the teaching and learning process.

\section{Product Revisions}

After a limited trial was carried out on the IHT module, there were suggestions for additional material from the teachers so that the steps for operating the Projector LCD were included in the learning material for the IHT module. This has the intention that teachers can practice independently in operating the LCD projector after the holding of IHT. After a product revision is made, the product design changes. At the end of the lesson, an evaluation exercise task is given which is used to measure how far the trainees are, so that participants can assess their individual abilities. At the end of the module, material about the operation of the LCD projector is added so that participants can present the slides that have been made using the LCD projector. The glossary aims to help participants understand some terms that cannot be explained in the learning material.

The results of the effectiveness or module testing show that during the training, the teachers were very enthusiastic and enthusiastic about being able to operate the multimedia they had and were available at SDN 12 Rambutan. Some of the teachers have started trying to present material in class, even though it is only simple but have been able to attract students' attention in the teaching and learning process. This is a stepping stone for teachers to become creative teachers in utilizing existing technology, so that the competence of information and communication technology (ICT) can increase and be able to face technological advances. With the arrangement of the IHT module, SDN 12 Rambutan teachers have independent provisions to face the teaching and learning process using the 2013 curriculum which is considered complex.

The compiled and validated IHT module is the final product in this study. This final product contains a preface, a table of contents, instructions for using modules, learning objectives, 8 learning materials which include: Introduction to PowerPoint 2007, Adjusting Presentation Format, Editing Text Format, Inserting Objects in Presentations, Managing Tables on Presentations, Modifying Presentations Using Animations, Utilization of the Internet, and Operation of the LCD Projector. Each learning material is given an evaluation exercise task and is closed with a difficult word arrangement contained in the glossary.

The IHT module is designed to be used as a medium for In House Training, which, if used properly, can improve ICT competence among elementary school teachers. In addition, this module can also be used as an independent learning medium in the use of the PowerPoint presentation application along with the use of the internet and the operation of the LCD projector. This IHT module is deemed fit to be used as an In House Training module in utilizing Microsoft Power Point presentation media.

This is in accordance with the opinion of [16] which states that a good module has characteristics, including self-instruction where participants can learn independently using modules. This has the aim, so that after IHT is held, the module can still be used as a medium for independent learning. Thus, the use of modules can be used at any time to improve the ICT competence of users.

The module also has a self-contained character where all the learning material needed by the participants is contained in the module. The learning materials needed by the participants are compiled after going through the needs analysis process. So that the material that is really needed can be accessed easily through the module. This module also does not contain learning material that is not currently needed by participants, because if it contains other materials, it will ensure that the trainees will be confused and lazy to practice. Stand alone is a character where the module does not depend on other media, or is not used together with other media. This module can be used to support all the material that the participants want to learn so that no other media is needed to be used together. In addition, the character of the module must be adaptive, that is, the module has high adaptation to the development of science and technology. This means that if there is a serial update in the Microsoft Office Power Point application, the module can be adjusted according to your needs. The last character in the module, namely the module must be user friendly, where the modules that are compiled can help participants, so that participants can use the module as they wish in ease.

Although it is declared suitable for use in training and independent study, this module also has a weakness, namely that it only consists of basic material for introducing Power Points. This can only provide facilities for teachers who are approaching retirement age, while for teachers who are young, the material in the module is considered too easy.

This research is better than some previous studies. Several previous studies that examined the benefits of training in increasing ICT competencies and also increasing the ability of subject teachers through IHT, the researchers used pre-existing modules. On the other hand this study carried out training to improve ICT competence by using modules that were compiled by researchers themselves. Thus, this study has a different appeal from previous studies. 


\section{CONCLUSION}

This research produces a final product in the form of an In House Training (IHT) module entitled "Knowing Power Point 2007" to improve ICT competence among elementary school teachers. The results of the validity trial showed that the module was declared fit for use in the limited trial at SDN 12 Rambutan. While the results of the limited trial, the module was declared acceptable and used as an IHT module to improve ICT competence among elementary school teachers.

In the final product, an IHT module contains 8 learning materials, namely: Introduction to PowerPoint 2007, Adjusting Presentation Format, Editing Text Format, Inserting Objects in Presentations, Managing Tables on Presentations, Modifying Presentations Using Animations, Utilizing the Internet and Operating the LCD Projector. The use of modules in In House Training (IHT) to improve ICT competence among elementary school teachers can be seen from the beginning of using multimedia as a learning medium in classrooms by some teachers.

\section{REFERENCES}

[1] Mulyasa. (2011). Pendidikan Bermutu dan Berdaya Saing. Bandung: PT Remaja Rosdakarya.

[2] Ismanto, B. (2014). Akuntabilitas Guru Dalam Pengembangan Keprofesian Berkelanjutan. Seminar Nasional Pendidikan 2014 - Ikatan Sarjana Pendidikan Indonesia Jawa Tengah .2. Saing.

[3] Effendi, D., \& Wahidy, A. (2019). Pemanfaatan Teknologi Dalam Proses Pembelajaran Menuju Pembelajaran Abad 21. Prosiding Seminar Nasional Pendidikan 125-129. Universitas PGRI Palembang.

[4] Reddi, U. V. (2003). A Handbook for TeacherDevelopers. Dalam Reddi, Usha V dan Sanjaya Mishra (Eds) : Multimedia as An Educational Tool. New Delhi: Commonwealth Educational Media Centre for Asia.
[5] Musfah, J. (2011). Peningkatan Kompetensi Guru: Melalui Pelatihan dan Sumber Belajar Teori dan Praktik. Jakarta: Kencana.

[6] Rivalina, R. (2015). Kompetensi teknologi informasi dan komunikasi guru dalam peningkatan kualitas pembelajaran. Jurnal Teknodik: 165-176.

[7] Undang-Undang Republik Indonesia No. 14 Tahun 2005 tentang Guru dan Dosen.

[8] Niarsa, A. (2013). Studi Kompetensi Guru dalam Memanfaatkan Media Pembelajaran Berbasis Teknologi Informasi dan Komunikasi (TIK) di SD Negeri 01 Ledok Kecematan Sambong Kabupaten Blora. Semarang (ID): Universitas Negeri Semarang.

[9] Batubara, H.H. (2015). Pengembangan Media Pembelajaran Interaktif pada Operasi Bilangan Bulat. Muallimuna: Jurnal Madrasah Ibtidaiyah, 1 (1), 2-3.

[10] Herlinda., Fitria, H., \& Puspita, Y. (2020). Implementasi Teknologi Informasi dan Komunikasi dalam Proses Pembelajaran Kurikulum 2013. Journal of Education Research. 1(2):125-133

[11] Sugiyono. (2017). Metode Penelitian Kuantitatif, Kualitatif, dan $R \& D$. Bandung: Alfabeta.

[12] Mulyatiningsih, E. (2014). Metode Penelitian Terapan Bidang Pendidikan. Bandung: Alfabeta.

[13] Irwantoro, N., \& Suryana, Y. (2016). Kompetensi Pedagogik. Surabaya: Genta Group Production.

[14] Nawawi. (1983). Administrasi dan Organisasi Bimbingan dan Penyuluhan. Jakarta: Ghalia Indonesia.

[15] Azwar, S. (2013). Sikap Manusia: Teori dan Pengukurannya. Yogyakarta : Pustaka pelajar

[16] Daryanto. (2013). Menyusun Modul Bahan Ajar Untuk Persiapan Guru Dalam Mengajar. Yogyakarta: Penerbit Gava Media. 